\title{
Impact of heat waves on the bud dormancy of grapevines
}

\author{
Rafael Anzanello ${ }^{1}$, Cláudia Martellet Fogaça² ${ }^{2}$ Gabriele Becker Delwing Sartori ${ }^{3}$, Tainan Graeff Tasso ${ }^{4}$
}

\begin{abstract}
The objective of this work was to evaluate the effect of heat waves on the bud dormancy of grapevines with contrasting chilling requirements. 'Chardonnay', 'Merlot' and 'Cabernet Sauvignon' hardwood cuttings were collected in vineyards of Veranópolis, State of Rio Grande do Sul, Brazil, and were exposed to constant $\left(7.2^{\circ} \mathrm{C}\right)$ or alternate $\left(7.2\right.$ and $18^{\circ} \mathrm{C}$ for $12 / 12$ hours $)$ temperatures, combined with zero, one or two days a week at $25^{\circ} \mathrm{C}$. Periodically, part of cuttings was transferred to $25^{\circ} \mathrm{C}$ for daily budburst evaluation. Endodormancy (dormancy controlled by cold) was overcome with 150 chilling hours $(\mathrm{CH})$ at $7.2^{\circ} \mathrm{C}$ in 'Chardonnay', $300 \mathrm{CH}$ in 'Merlot' and $400 \mathrm{CH}$ in 'Cabernet Sauvignon'. Daily temperature cycles ranging from $7.2^{\circ} \mathrm{C}$ to $18^{\circ} \mathrm{C}$ did not affect the endodormancy process. Heat waves of $25^{\circ} \mathrm{C}$ resulted in increase in $\mathrm{CH}$ to overcome endodormancy. The negative effect of heat waves depended on their duration, with heat partially canceling out the chilling accumulation after 36 continuous hours on the dormancy. Such evidence shows that the dormancy evolution is affected by the impact of the heat interspersed with cold, and should be considered in the adjustment and/or development of better-adapted models for the prediction of the budburst potential of the grapevine culture in Southern Brazil.
\end{abstract}

Index terms: budburst, chilling hours, climate change, dormancy models, endodormancy.

\section{Impacto de ondas de calor na dormência de gemas de videiras}

\begin{abstract}
Corresponding author: rafael-anzanello@agricultura. rs.gov.br

Received: July 23, 2021

Accepted: November 03, 2021

Copyright: All the contents of this journal, except where otherwise noted, is licensed under a Creative Commons Attribution License.
\end{abstract}

Resumo - Este trabalho objetivou avaliar o efeito de ondas de calor na dormência de gemas de videiras com necessidades contrastantes de frio hibernal. Estacas lenhosas de videiras 'Chardonnay', 'Merlot' e 'Cabernet Sauvignon' foram coletadas em vinhedos de Veranópolis-RS, e expostas a temperatura constante $\left(7,2^{\circ} \mathrm{C}\right)$ ou alternada $\left(7,2\right.$ e $18^{\circ} \mathrm{C}$, por $12 / 12$ horas $)$, combinadas com zero, um ou dois dias por semana a $25^{\circ} \mathrm{C}$. Periodicamente, parte das estacas era transferida para $25^{\circ} \mathrm{C}$, para avaliação da brotação das gemas. A endodormência (dormência controlada pelo frio) foi superada com 150 horas de frio (HF) a 7, $2^{\circ} \mathrm{C}$ em 'Chardonnay', $300 \mathrm{HF}$ em 'Merlot' e $400 \mathrm{HF}$ em 'Cabernet Sauvignon'. Ciclos diários de temperaturas, variando de $7,2^{\circ} \mathrm{C}$ a $18^{\circ} \mathrm{C}$, não afetaram o processo de endodormência. Ondas de calor de $25^{\circ} \mathrm{C}$ resultaram em aumento de HF para a superação da endodormência. $\mathrm{O}$ efeito negativo das ondas de calor dependeu de sua duração, sendo que o calor anulou parcialmente o acúmulo de frio após 36 horas contínuas na dormência. Tais evidências mostram que a evolução da dormência é afetada pelo impacto do calor intercalado ao frio hibernal, devendo ser considerada no ajuste e/ou no desenvolvimento de modelos mais adaptados para a predição do potencial de brotação de videiras no Sul do Brasil.

Termos para indexação: brotação, horas de frio, mudanças climáticas, modelos de dormência, endodormência.

IPh.D, Researcher, Department of Diagnosis and Agricultural Research, Secretariat of Agriculture, Livestock and Rural Development, Veranópolis-RS, Brazil. Email: rafael-anzanello@agricultura.rs.gov.br (ORCID 0000-0002-2406-2789)

${ }^{2} \mathrm{Ph} . \mathrm{D}$, Researcher, Department of Diagnosis and Agricultural Research, Secretariat of Agriculture, Livestock and Rural Development, Veranópolis-RS, Brazil. Email: claudia-fogaça@agricultura.rs.gov.br(ORCID 0000-0001-7720-7796)

${ }^{3}$ Laboratory Research Technician, Department of Diagnosis and Agricultural Research, Secretariat of Agriculture, Livestock and Rural Development, Veranópolis-RS, Brazil. Email: gabriele-sartori@seapdr.rs.gov.br (ORCID 0000-0001-5370-2872)

${ }^{4}$ Undergraduate Agronomy student, University of Caxias do Sul, Caxias do Sul-RS, Brazil. Email: tgtasso@ucs.br (ORCID 0000-0001-6215-3406) 


\section{Introduction}

In temperate and subtropical climates, fruit species such as grapevine present bud dormancy in the autumn and winter, with temporary suspension of visible plant growth. According to Lang et al. (1987), there are three types of dormancy, called paradormancy, endodormancy and ecodormancy. In paradormancy, the absence of bud development is the result of the influence of another plant organ, such as apical dominance. In endodormancy, budburst inhibition results from a series of biochemical and physiological events at meristematic levels or close tissues, triggered by the perception of an environmental stimulus, which is usually caused by low temperatures, photoperiod changes or both. This type of dormancy can occur with different duration and intensity (depth), being overcome with the accumulation of a certain number of chilling hours $(\mathrm{CH})$ during autumn and winter, ranging from 100 to $2000 \mathrm{CH}$, according to species and cultivar (HAWERROTH et al., 2010). After overcoming the endodormancy, budburst depends on spring environmental conditions, especially temperature and water availability, in the state called ecodormancy.

For Carvalho and Zanette (2006) and Campoy et al. (2011), in a productive system, not supplying the chilling requirement during dormancy can cause serious phenological problems, such as insufficient and/or uneven budburst and flowering. Poor or uneven budburst can compromise both the production and the distribution of branches in plants, whereas poor and uneven flowering can impair pollination and, consequently, fruiting efficiency.

In the climatic conditions of southern Brazil, large thermal fluctuations during autumn and winter are common (FELIPPETO et al., 2013). If the chilling requirements of fruit cultivars are not fully met in the field during the winter period, products can be used to induce budburst (PETRI et al., 2021). The use of chemical products to overcome dormancy is a worrying factor due to their toxicity, with hydrogen cyanamide being the main compound (HAWERROTH et al., 2010). However, there are products that can be used in the organic system (PETRI et al., 2021), such as garlic extract (BOTELHO et al., 2010), and nutritional compounds based on Erger ${ }^{\circledR}$ fertilizer with calcium nitrate, as options for viticulture (WATANABE et al., 2017).

To measure the chilling requirement to overcome bud endodormancy, the method most commonly used is the accumulation of Chilling Hours $(\mathrm{CH})$, with temperatures $\leq 7.2^{\circ} \mathrm{C}$ (WEINBERGER, 1950). However, this model is limited, since it does not consider that temperatures above $7.2^{\circ} \mathrm{C}$ can be efficient to overcome dormancy (LUEDELING; BROWN, 2011). There are also other models for estimating $\mathrm{CH}$ accumulation, such as the Utah (RICHARDSON et al., 1974), North Carolina (SHALTOUT; UNRATH, 1983) and modified Utah and
North Carolina (EBERT et al., 1986) models, whose values are expressed in Chill Units (CU) and do not consider a fixed temperature value. These CU models have wider range of effective temperatures and incorporate negative effects for higher temperatures.

It is noteworthy that most models designed to overcome dormancy (WEINBERGER, 1950; RICHARDSON et al., 1974; SHALTOUT; UNRATH, 1983) were developed and adjusted to the North American climatic conditions, characterized by constant and regular autumns and winters, and validated for peach and apple crops. For the southern Brazilian climate conditions (main grape production region), where large thermal fluctuations occur during the autumn and winter period, these models are unreliable, requiring adjustments (FELIPPETO et al., 2013; ANZANELLO et al., 2014a). Heat and cold variations in the evolution and overcoming dormancy should be better studied, mainly characterizing the impact of alternate heat during the winter period in order to adjust or develop more adapted models for predicting the budburst potential of fruit crops in southern Brazil. From a precise modeling, producers and technicians will have an important tool for decision making in budburst management practices, reducing costs and increasing the efficiency of treatments in terms of dosages and environmental impacts (ANZANELLO et al., 2021).

The problem of overcoming dormancy tends to be aggravated with the expansion of grapevine growing areas, mainly to marginal regions (GUO et al., 2014). In addition, there are prospects of increase in global temperature due to the intensification of the effect of greenhouse gases, with tendency towards a progressive decrease in the availability of chilling hours in the state of Rio Grande do Sul (CARDOSO et al., 2012). This climatic change can directly impact the state of endodormancy and the budburst capacity of grapevine and other temperate climate fruit species. The hypothesis of this work consisted of evaluating the response of grapevine genotypes with contrasting chilling requirements regarding the winter conditions with constant or unstable temperatures, simulating daily cycles of temperatures and heat waves, allowing the development or adjustment of more effective models for predicting the beginning of the annual crop vegetative cycle.

The aim of this work was to evaluate the impact of heat waves on the bud dormancy of grapevines with contrasting chilling requirements.

\section{Material and methods}

'Chardonnay', 'Merlot' and 'Cabernet Sauvignon' hardwood cuttings were collected in commercial vineyards in the municipality of Veranópolis - RS, Serra Gaúcha, Brazil, in the winter period of 2021, with zero $\mathrm{CH}$ in the 
field. Plants were cultivated in a trellis system, grafted on Paulsen 1103 rootstock, pruned in a mixed pruning system, with 10 years of age. Cuttings were collected from the middle part of branches, measuring 30 to $40 \mathrm{~cm}$ in length, approximately $1 \mathrm{~cm}$ in diameter, containing 5 buds per cutting, without the presence of leaves. Buds used in this study were found between the $3^{\text {rd }}$ and $8^{\text {th }}$ bud of branches. In the selection of material for collection, the maturity of buds (well closed buds), the health and vigor of cuttings were considered, prioritizing those with intermediate growth.

After collection, cuttings were wrapped in bundles with newspaper sheets, moistened, placed in plastic bags and transported to the Department of Diagnostics and Agricultural Research (DDPA), of the Secretariat of Agriculture, Livestock and Rural Development of the State of Rio Grande do Sul (SEAPDR), Veranópolis-RS, to evaluate bud dormancy under controlled conditions. Cuttings underwent a cleaning process, according to methodology proposed by Anzanello et al. (2014b).

After disinfestation, cuttings were processed by cutting one end in a bevel, approximately $1 \mathrm{~cm}$ above the bud, and the other one approximately $7 \mathrm{~cm}$ below the first cut, forming single-node cuttings (cuttings with a single bud). Cuttings were inserted in pots with moistened phenolic foam and submitted to constant $\left(7.2^{\circ} \mathrm{C}\right)$ or alternate temperature $\left(7.2\right.$ and $18^{\circ} \mathrm{C}$, for $12 / 12$ hours) in Eletrolab incubator chambers, model EL202, combined with zero, one or two days per week at $25^{\circ} \mathrm{C}$, until reaching $600 \mathrm{CH}$, considering for the cold calculation only the hours kept at $7.2^{\circ} \mathrm{C}$. At every $50 \mathrm{CH}$, part of cuttings from each treatment was transferred to temperature of $25{ }^{\circ} \mathrm{C}$ and photoperiod of $12 \mathrm{~h}$ of light, for the induction and evaluation of the budburst in the green tip stage (CARVALHO et al., 2010). The experimental design was randomized block in a $3 \times 6 \times 12$ factorial scheme (cultivar $\mathrm{x}$ thermal regime $\mathrm{x}$ chill exposure time), with each combination composed of three replicates (3 pots with 10 cuttings each). The adoption of the block design aimed to control possible differences in air circulation inside incubator chambers.

Cuttings in incubator chambers were irrigated every 48-72 hours, replacing the water to saturate the phenolic foam. The preventive control of diseases in cuttings was carried out by using chemical pesticides containing difenoconazole and tebuconazole (systemic) and iprodione and captan (contact), sprayed at dosage of 1.5 to $2.0 \mathrm{ml}$ $\mathrm{L}^{-1}$, except for tebuconazole, for which dosage was $1.0 \mathrm{ml}$ $\mathrm{L}^{-1}$. Pesticides were applied every 14 to 21 days, switching between contact and systemic products.

Budburst was assessed every 2-3 days until the $35^{\text {th }}$ day. Data on the final budburst rate (percentage of budburst), precocity (number of days until the budburst of the first bud) and uniformity (number of days between the first and last bud sprouted) were submitted to analysis of variance (ANOVA). Using the F test, results with significant differences had means compared by the Tukey test at $5 \%$ significance level.

\section{Results and discussion}

A total of approximately 150,300 and $400 \mathrm{CH}$ were needed to overcome the bud dormancy of 'Chardonnay', 'Merlot' and 'Cabernet Sauvignon', respectively, under constant thermal regime of $7.2^{\circ} \mathrm{C}$ (Figure 1). Overcoming dormancy was considered when there were $70 \%$ or more sprouted buds (ANZANELLO; LAMPUGNANI, 2000). This chilling requirement was similar to that observed by Anzanello et al. (2018), working with the same grapevine cultivars under constant thermal regime of $3^{\circ} \mathrm{C}$. The alternating regime of $7.2^{\circ} \mathrm{C}$ and $18^{\circ} \mathrm{C}$, for $12 / 12 \mathrm{~h}$, did not change the chilling requirement of cultivars, which remained at $150 \mathrm{CH}$ for 'Chardonnay', $300 \mathrm{CH}$ for 'Merlot' and $400 \mathrm{CH}$ for 'Cabernet' Sauvignon' (Figure 1). Of this total, $50 \mathrm{CH}$ for 'Chardonnay' and 'Merlot' and $100 \mathrm{CH}$ for 'Cabernet Sauvignon' were required for dormancy induction (Figure 1), for all thermal regimes (constant and alternate), signaled by the reduction in the initial budburst capacity. 

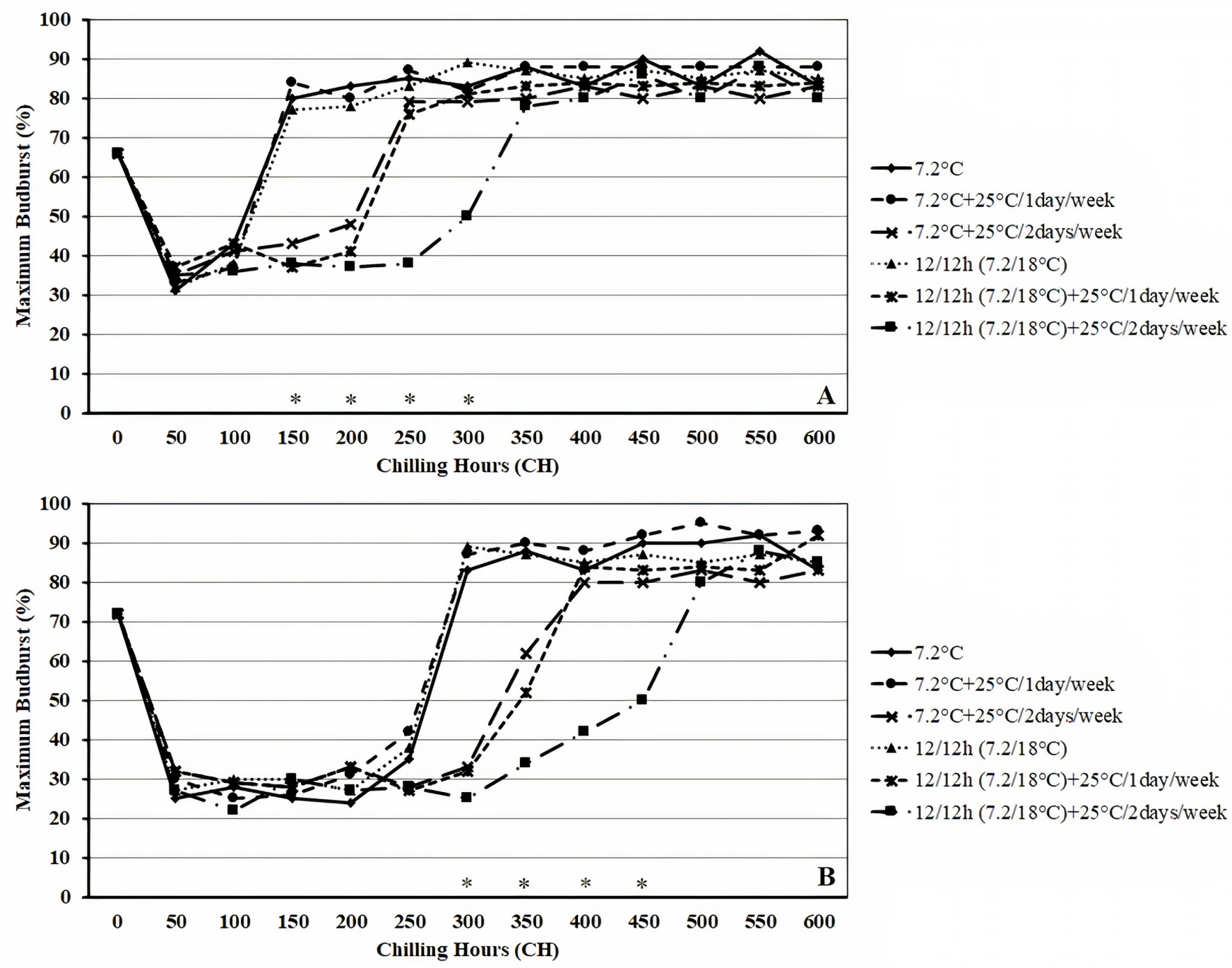

$\rightarrow 7.2^{\circ} \mathrm{C}$

-๑ $7.2^{\circ} \mathrm{C}+25^{\circ} \mathrm{C} / 1$ day/week

$* * 7.2^{\circ} \mathrm{C}+25^{\circ} \mathrm{C} / 2$ days $/$ week

….. 12/12h $\left(7.2 / 18^{\circ} \mathrm{C}\right)$

- * 12/12h $\left(7.2 / 18^{\circ} \mathrm{C}\right)+25^{\circ} \mathrm{C} / 1$ day $/$ week

$\rightarrow \cdot 12 / 12 \mathrm{~h}\left(7.2 / 18^{\circ} \mathrm{C}\right)+25^{\circ} \mathrm{C} / 2$ days $/$ week

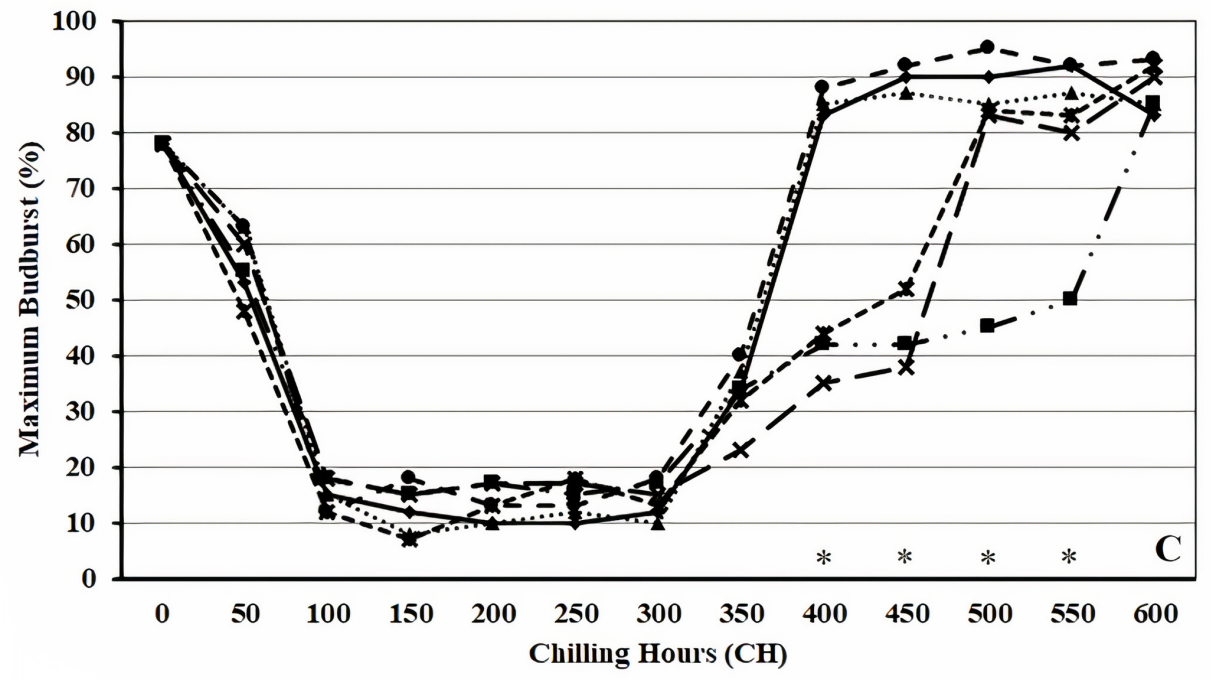

$\rightarrow 7.2^{\circ} \mathrm{C}$

-0 $7.2^{\circ} \mathrm{C}+25^{\circ} \mathrm{C} / 1$ day/week

$\rightarrow \cdot 7.2^{\circ} \mathrm{C}+25^{\circ} \mathrm{C} / 2$ days $/$ week

…*12/12h $\left(7.2 / 18^{\circ} \mathrm{C}\right)$

- * $12 / 12 \mathrm{~h}\left(7.2 / 18^{\circ} \mathrm{C}\right)+25^{\circ} \mathrm{C} / 1$ day/week

$\rightarrow \cdot 12 / 12 \mathrm{~h}\left(7.2 / 18^{\circ} \mathrm{C}\right)+25^{\circ} \mathrm{C} / 2$ days $/$ week

Figure 1 - Maximum budburst of 'Chardonnay' (A), 'Merlot' (B) and 'Cabernet Sauvignon' (C) grapevines submitted to constant temperature of $7.2^{\circ} \mathrm{C}$, alternating temperatures of $7.2 / 18^{\circ} \mathrm{C}$ and heat waves in the middle of the cold during the dormancy period. Veranópolis, 2021. Significant differences in maximum budburst within each cold period by the Tukey test $(\mathrm{p}<0.05)$ are marked with $(*)$. Description of treatments: $7.2^{\circ} \mathrm{C} \rightarrow 7.2^{\circ} \mathrm{C}$ constant; $7.2^{\circ} \mathrm{C}+25^{\circ} \mathrm{C} / 1 \mathrm{day} /$ week $\rightarrow 7.2^{\circ} \mathrm{C}$ constant with heat waves 1 day per week at $25^{\circ} \mathrm{C} ; 7.2^{\circ} \mathrm{C}+25^{\circ} \mathrm{C} / 2$ days/week $\rightarrow 7.2^{\circ} \mathrm{C}$ constant with heat waves 2 days per week at $25^{\circ} \mathrm{C} ; 12 / 12 \mathrm{~h}\left(7.2 / 18^{\circ} \mathrm{C}\right)+25^{\circ} \mathrm{C} / 1$ day/week $\rightarrow$ daily cycles of 12 hours at $7.2^{\circ} \mathrm{C}$ and 12 hours at $18^{\circ} \mathrm{C}$, with heat waves of 1 day per week at $25^{\circ} \mathrm{C} ; 12 / 12 \mathrm{~h}\left(7.2 / 18^{\circ} \mathrm{C}\right)+25^{\circ} \mathrm{C} / 2$ days/week $\rightarrow$ daily cycles of 12 hours at $7.2^{\circ} \mathrm{C}$ and 12 hours at $18^{\circ} \mathrm{C}$, with heat waves 2 days per week at $25^{\circ} \mathrm{C}$. 
The similar efficiency among treatments in inducing endodormancy indicates that, for grapevine buds to trigger endodormancy, it only takes a few daily chilling hours, and not extremely low and constant temperatures, in the autumn/winter period. The effectiveness of alternate temperatures in inducing endodormancy was also reported by Aldermann et al. (2011), who claim that the effect of low temperatures in mild autumnal temperatures provides recognition of the signal that triggers the bud dormancy mechanism. This effect causes changes in the meristematic tissues of buds, which affect their ability to resist cold. Anzanello et al. (2014a) also found positive effect of alternating cold and heat temperatures $\left(3\right.$ and $\left.15^{\circ} \mathrm{C}\right)$ on the entrance of apple bud endodormancy, with its efficiency similar to the constant temperature of $3^{\circ} \mathrm{C}$, working with 'Castel Gala' and 'Royal Gala' cultivars.

The Chardonnay cultivar showed light depth dormancy, with $30-40 \%$ budburst rate in the period of maximum endodormancy, and Merlot and Cabernet Sauvignon cultivars showed deeper dormancy, reaching at the same stage, $20-30 \%$ budburst rate for 'Merlot' and $10-20 \%$ for 'Cabernet Sauvignon' (Figure 1). Considering the dormancy evolution, there is a direct relationship between dormancy depth and the total chilling requirement of cultivars. The greater the dormancy depth level, the greater the chilling requirement. Similar relationships were observed in apple trees, in which total $\mathrm{CH}$ is associated with the dormancy depth level of cultivars (ANZANELLO et al., 2014a).

The effect of short heat periods $\left(25^{\circ} \mathrm{C}\right)$ on the chilling requirement of cultivars was variable, depending on the applied thermal regime. At constant temperature $\left(7.2^{\circ} \mathrm{C}\right), 24$ hours per week at $25^{\circ} \mathrm{C}$ did not change the chilling requirement (Figure 1). However, 48 hours per week at $25^{\circ} \mathrm{C}$ increased the chilling requirement of all cultivars by approximately 100 hours. Under alternating temperatures $\left(7.2 / 18^{\circ} \mathrm{C}\right.$ cycle), exposure to $25^{\circ} \mathrm{C}$ for 24 and 48 hours per week increased chilling requirements by approximately 100 and 200 hours, respectively. Three groups were formed among treatments. Thermal regimes at a constant $7.2^{\circ} \mathrm{C}$, with alternating $7.2 / 18^{\circ} \mathrm{C}(12 / 12 \mathrm{~h})$ and $7.2^{\circ} \mathrm{C}$ once per week at $25^{\circ} \mathrm{C}$ did not differ from each other and required, on average, $150 \mathrm{CH}$ to overcome dormancy in 'Chardonnay' (Figure 1A), $300 \mathrm{CH}$ in 'Merlot' (Figure 1B) and $400 \mathrm{CH}$ in 'Cabernet Sauvignon' (Figure 1 C). Treatments at $7.2^{\circ} \mathrm{C}$ with two days per week at $25^{\circ} \mathrm{C}$ and the alternating regime $7.2 / 18^{\circ} \mathrm{C}(12 / 12 \mathrm{~h})$ with one day per week at $25^{\circ} \mathrm{C}$ increased to $250 \mathrm{CH}$ to overcome dormancy in 'Chardonnay' (Figure 1A), $400 \mathrm{CH}$ in 'Merlot' (Figure 1B) and $500 \mathrm{CH}$ in 'Cabernet Sauvignon' (Figure 1C). The alternating treatment $7.2 / 18^{\circ} \mathrm{C}(12 / 12 \mathrm{~h})$ with two days per week at $25^{\circ} \mathrm{C}$ required approximately $350 \mathrm{CH}$ in 'Chardonnay' (Figure 1A), $500 \mathrm{CH}$ in 'Merlot' (Figure 1B) and $600 \mathrm{CH}$ in 'Cabernet Sauvignon' (Figure 1C) during dormancy. Similar relationships were obtained by Anzanello (2019) with 'Itália' grape cultivar and by Anzanello et al. (2014a) with 'Castel Gala' and 'Royal Gala' apple cultivars, after application of thermal regimes with cold and heat fluctuations during the dormancy period.

In general, $\mathrm{CH}$ requirement varied between 150 and $350 \mathrm{CH}$ for 'Chardonnay', 300 and $500 \mathrm{CH}$ for 'Merlot' and 400 and $600 \mathrm{CH}$ for 'Cabernet Sauvignon', depending on the thermal regime (Table 1). For Petri et al. (2021), the current $\mathrm{CH}$ model for overcoming bud dormancy of fruit plants is not satisfactory, as it disregards the effect of a wider range of temperatures, making it difficult to establish the number of $\mathrm{CH}$ necessary for cultivars to overcome dormancy in years with variable temperature regimes. According to Luedeling and Brown (2011), the $\mathrm{CH}$ model is inadequate to estimate the number of chilling hours to overcome dormancy and reach budburst, as it oversimplifies the biochemical dormancy process for a simple function of temperature. According to Petri et al. (2021), the CH method provides only an idea, and it can be used to classify species and cultivars according to their degree of chilling requirement. 
TABLE 1 - Amount of chill to overcome dormancy estimated by the Chilling Hours $\left(\mathrm{CH} \leq 7.2^{\circ} \mathrm{C}\right)$, Utah (UT), North Carolina (CN), Modified Utah (UTm) and Modified North Carolina (CNm) models for Chardonnay $(\mathrm{CH})$, Merlot (M) and Cabernet Sauvignon (CS) cultivars, Veranopolis, 2021.

\begin{tabular}{|c|c|c|c|c|c|c|}
\hline \multirow[b]{2}{*}{ Treatment } & \multirow[b]{2}{*}{ Cultivar } & \multicolumn{5}{|c|}{ Models } \\
\hline & & $\begin{array}{c}\mathrm{CH} \\
\leq 7.2^{\circ} \mathrm{C}\end{array}$ & UT & $\mathrm{CN}$ & $\mathrm{UTm}$ & $\mathrm{CNm}$ \\
\hline $7.2^{\circ} \mathrm{C}$ constant & $\mathrm{CH}$ & 150 & 150 & 150 & 150 & 150 \\
\hline $7.2^{\circ} \mathrm{C}+25^{\circ} \mathrm{C} / 1$ day $/$ week & $\mathrm{CH}$ & 150 & 126 & 102 & 126 & 102 \\
\hline $7.2^{\circ} \mathrm{C}+25^{\circ} \mathrm{C} / 2$ days/week & $\mathrm{CH}$ & 250 & 154 & 58 & 154 & 58 \\
\hline $12 / 12 \mathrm{~h}\left(7.2 / 18^{\circ} \mathrm{C}\right)$ & $\mathrm{CH}$ & 150 & 78 & 78 & 78 & 78 \\
\hline $12 / 12 \mathrm{~h}\left(7.2 / 18^{\circ} \mathrm{C}\right)+25^{\circ} \mathrm{C} / 1$ day/week & $\mathrm{CH}$ & 250 & 58 & -14 & 58 & -14 \\
\hline $12 / 12 \mathrm{~h}\left(7.2 / 18^{\circ} \mathrm{C}\right)+25^{\circ} \mathrm{C} / 2$ days/week & $\mathrm{CH}$ & 350 & -112 & -400 & -112 & -400 \\
\hline $7.2^{\circ} \mathrm{C}$ constant & M & 300 & 300 & 300 & 300 & 300 \\
\hline $7.2^{\circ} \mathrm{C}+25^{\circ} \mathrm{C} / 1$ day $/$ week & M & 300 & 252 & 204 & 252 & 204 \\
\hline $7.2^{\circ} \mathrm{C}+25^{\circ} \mathrm{C} / 2$ days/week & M & 400 & 256 & 112 & 256 & 112 \\
\hline $12 / 12 \mathrm{~h}\left(7.2 / 18^{\circ} \mathrm{C}\right)$ & M & 300 & 222 & 222 & 222 & 222 \\
\hline $12 / 12 \mathrm{~h}\left(7.2 / 18^{\circ} \mathrm{C}\right)+25^{\circ} \mathrm{C} / 1$ day/week & M & 400 & 58 & -86 & 58 & -86 \\
\hline $12 / 12 \mathrm{~h}\left(7.2 / 18^{\circ} \mathrm{C}\right)+25^{\circ} \mathrm{C} / 2$ days $/$ week & M & 500 & -130 & -514 & -130 & -514 \\
\hline $7.2^{\circ} \mathrm{C}$ constant & $\mathrm{CS}$ & 400 & 400 & 400 & 400 & 400 \\
\hline $7.2^{\circ} \mathrm{C}+25^{\circ} \mathrm{C} / 1 \mathrm{day} /$ week & $\mathrm{CS}$ & 400 & 328 & 256 & 328 & 256 \\
\hline $7.2^{\circ} \mathrm{C}+25^{\circ} \mathrm{C} / 2$ days/week & $\mathrm{CS}$ & 500 & 308 & 116 & 308 & 116 \\
\hline $12 / 12 \mathrm{~h}\left(7.2 / 18^{\circ} \mathrm{C}\right)$ & $\mathrm{CS}$ & 400 & 274 & 274 & 274 & 274 \\
\hline $12 / 12 \mathrm{~h}\left(7.2 / 18^{\circ} \mathrm{C}\right)+25^{\circ} \mathrm{C} / 1$ day $/$ week & $\mathrm{CS}$ & 500 & 86 & -82 & 86 & -82 \\
\hline $12 / 12 \mathrm{~h}\left(7.2 / 18^{\circ} \mathrm{C}\right)+25^{\circ} \mathrm{C} / 2$ days/week & $\mathrm{CS}$ & 600 & -180 & -660 & -180 & -660 \\
\hline
\end{tabular}

The Utah (RICHARDSON et al., 1974) and North Carolina (SHALTOUT; UNRATH, 1983) chill unit $(\mathrm{CU})$ models attribute a negative temperature effect of $18^{\circ} \mathrm{C}$ to weight of $-0.5 \mathrm{CU}$. In the present study, constant temperature of $7.2^{\circ} \mathrm{C}$ or alternating temperature of $7.2 / 18^{\circ} \mathrm{C}(12 / 12 \mathrm{~h})$ did not differ in the response pattern of each cultivar to cold, being insensitive to the inclusion of alternating higher temperature $\left(18^{\circ} \mathrm{C}\right)$. The Utah and North Carolina models also attribute the negative effect of temperature of $25^{\circ} \mathrm{C}$ to weights of $-1 \mathrm{CU}$ and $-2 \mathrm{CU}$ per hour, respectively (RICHARDSON et al., 1974; SHALTOUT; UNRATH, 1983). The Modified Utah and Modified North Carolina (EBERT et al., 1986) models consider that the negative effect occurs only during the first 96 hours of continuous heat. All four models proved to be inaccurate when the thermal regime included heat waves (Table 1). An ideal model would estimate the same chilling requirement (CU), regardless of thermal regime
(ANZANELLO et al., 2018). CU models do not seem to be better than the $\mathrm{CH}$ method and, in some cases, they may be worse regarding the thermal regimes applied in the present study, as can be observed by the negative estimates of chill units to overcome dormancy (Table 1). CU models considered effective for predicting budburst (EBERT et al., 1986; EREZ, 2000; LEGAVE et al., 2008) seem to be unreliable and, in most cases, are inaccurate in the presence of heat waves. Therefore, their use is limited to southern Brazil conditions, suggesting that changes and/ or adjustments occur during their modeling process.

For Luedeling and Brown (2011), temperature fluctuations require increasing the amount of chill during the bud dormancy of temperate fruits. Erez and Lavee (1971) found that the negative effect of high temperatures depends on their intensity and duration. According to these authors, exposures from 2 to $4 \mathrm{~h}$ at $21{ }^{\circ} \mathrm{C}$ were not harmful. However, when longer than $8 \mathrm{~h}$, they had the effect of canceling out the chilling hours. The present study 
suggests that only after 36 hours, heat cancels out part of the accumulated chill effect. In alternating temperature regimes, the 24 or 48 hours at $25^{\circ} \mathrm{C}$ were always followed by 12 hours at $18^{\circ} \mathrm{C}$, totaling 36 or 60 hours of absence of chill. These conditions reversed the dormancy process and increased the chilling requirement of cultivars (Figure 1), reinforcing the need for adjustments in usual dormancy models (RICHARDSON et al., 1974; SHALTOUT; UNRATH, 1983), which consider an effect of immediate reversal of high temperatures on the accumulation of chill units. Models must partially cancel out the chill effect only after 36 hours of heat, with the dormancy process immune to the influence of high temperatures before this period. One of the main shortcomings of current dormancy models when used in the southern region of Brazil is not adequately estimating the chilling requirements of genotypes under intermittent heat wave conditions in the winter period (ANZANELLO, 2019), such as those tested in this work.

Budburst precocity and uniformity followed a similar response pattern with the evolution of endodormancy, not being affected by thermal regime or cultivar (Figures 2 and 3). In the case of precocity, up to the period of maximum endodormancy, the number of days required to reach budburst increased, decreasing as dormancy was overcome (Figure 2), a trend also observed by LEITE et al. (2014) in peach, ALVAREZ et al. (2018) in grapevine and NOAR et al. (2003) in apple trees. For Hawerroth et al. (2009), the budburst time is related to the depth of the buds' endodormancy state. Budburst precocity increased with the longer chilling duration, especially after overcoming the endodormancy. Legave et al. (2008), working with apple trees, reported that the need for heat units for the beginning of the vegetative cycle is smaller the greater the number of accumulated chilling hours, corroborating results obtained in this study.

During induction and full endodormancy, budburst uniformity values showed greater variability. After this period was over, budburst was more uniform and regular (Figure 3). Such behavior demonstrates the importance of the occurrence of low temperatures during the autumn/winter to overcome dormancy and to ensure adequate budburst uniformity at the beginning of the vegetative cycle. According to Campoy et al. (2011) and Marafon et al. (2011), supplying chilling requirements during endodormancy is essential to avoid phenological disorders, such as insufficient and/or uneven budburst and flowering in temperate climate fruit trees.

The knowledge of factors and processes that affect dormancy is essential to develop models related to bud physiology during the winter period and early budburst. For this, methods that reproduce field conditions and enable isolated tests for different factors are essential (HAWERROTH et al., 2010). There are several biological methods to evaluate budburst for dormancy modeling using whole plants (in pots or grafted branches) or parts of them, such as detached branches and single-node cuttings (WAGNER JUNIOR et al., 2006). Methods that use whole plants allow assessing interactions between buds and other tissues or organs, but demand large spaces in climatized chambers and increase research costs. In addition, the application of various thermal treatments is difficult, which impairs adjusting accurate models to estimate the dormancy state (ANZANELLO et al., 1014a). Therefore, in this work, tests under controlled conditions were prioritized, isolating the effect of the air temperature variable, with the single-node method, to work with large number of buds in small spaces, allowing a greater range of response to different thermal conditions.

Anzanello et al. (2018) working with 'Chardonnay', 'Merlot' and 'Cabernet Sauvignon' using whole 5-bud cuttings (cuttings of 40-60 cm), with preservation of the interaction between buds in branches, achieved the same chilling requirements to overcome dormancy (150, 300 and $400 \mathrm{CH}$, respectively), compared to those observed with single-node cuttings. Therefore, the same effect was maintained regarding the chilling requirement of cultivars, regardless of biological method used. In addition, in a crop (2020) previous to that of the present study and with the same cultivars, also in Serra Gaúcha, Anzanello et al. (2021) obtained identical results when constant regimes and daily temperature cycles were tested $\left(7.2 / 18^{\circ} \mathrm{C}\right.$, for $6 / 12 \mathrm{~h}, 12 / 12 \mathrm{~h}$ and $\left.18 / 6 \mathrm{~h}\right)$ during dormancy, giving representativeness and consistency to information obtained in the present work. Regarding the effect of heat waves during dormancy, Anzanello et al. (2014b) and Anzanello (2019), working with apple trees and table grapes, respectively, also concluded that heat cancels out accumulated chill after 36 continuous hours, showing that the effect of heat on dormancy has a linear relationship among temperate climate fruit species, supporting the present proposition for future adjustments in the dormancy modeling. 

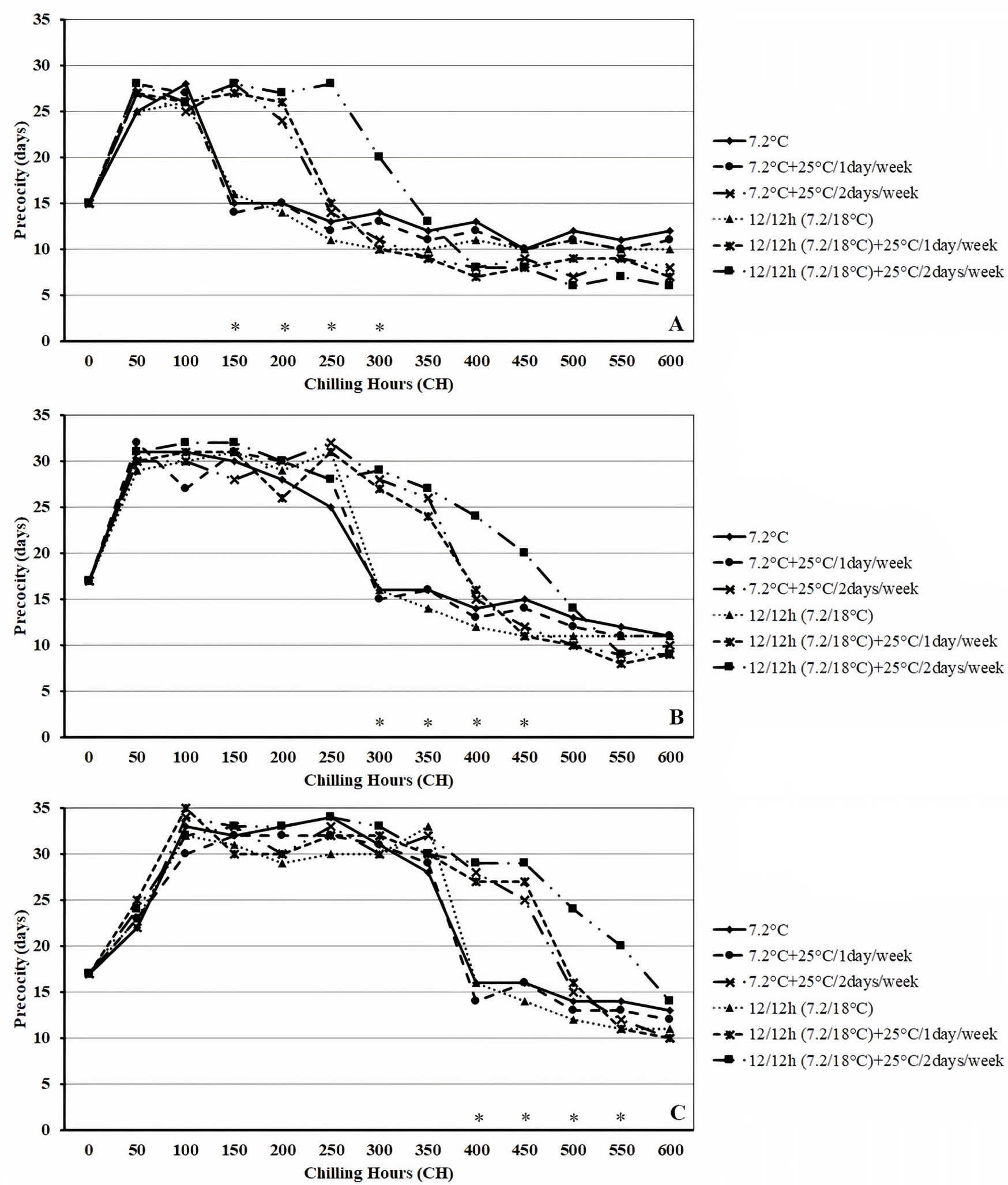

Figure 2 - Budburst precocity of 'Chardonnay' (A), 'Merlot' (B) and 'Cabernet Sauvignon' (C) grapevines submitted to constant temperature of $7.2^{\circ} \mathrm{C}$, alternating temperatures of $7.2 / 18^{\circ} \mathrm{C}$ and heat waves in the middle of the cold during the dormancy period. Veranópolis, 2021. Significant differences in budburst precocity, within each cold period, by the Tukey test $(\mathrm{p}<0.05)$, are marked with $(*)$. Description of treatments: $7.2^{\circ} \mathrm{C} \rightarrow 7.2^{\circ} \mathrm{C}$ constant; $7.2^{\circ} \mathrm{C}+25^{\circ} \mathrm{C} / 1$ day/ week $\rightarrow 7.2^{\circ} \mathrm{C}$ constant with heat waves 1 day per week at $25^{\circ} \mathrm{C} ; 7.2^{\circ} \mathrm{C}+25^{\circ} \mathrm{C} / 2 \mathrm{days} /$ week $\rightarrow 7.2^{\circ} \mathrm{C}$ constant with heat waves 2 days per week at $25^{\circ} \mathrm{C} ; 12 / 12 \mathrm{~h}\left(7.2 / 18^{\circ} \mathrm{C}\right)+25^{\circ} \mathrm{C} / 1$ day/week $\rightarrow$ daily cycles of 12 hours at $7.2^{\circ} \mathrm{C}$ and 12 hours at $18^{\circ} \mathrm{C}$, with heat waves of 1 day per week at $25^{\circ} \mathrm{C} ; 12 / 12 \mathrm{~h}\left(7.2 / 18^{\circ} \mathrm{C}\right)+25^{\circ} \mathrm{C} / 2$ days/week $\rightarrow$ daily cycles of 12 hours at $7.2^{\circ} \mathrm{C}$ and 12 hours at $18^{\circ} \mathrm{C}$, with heat waves 2 days per week at $25^{\circ} \mathrm{C}$. 

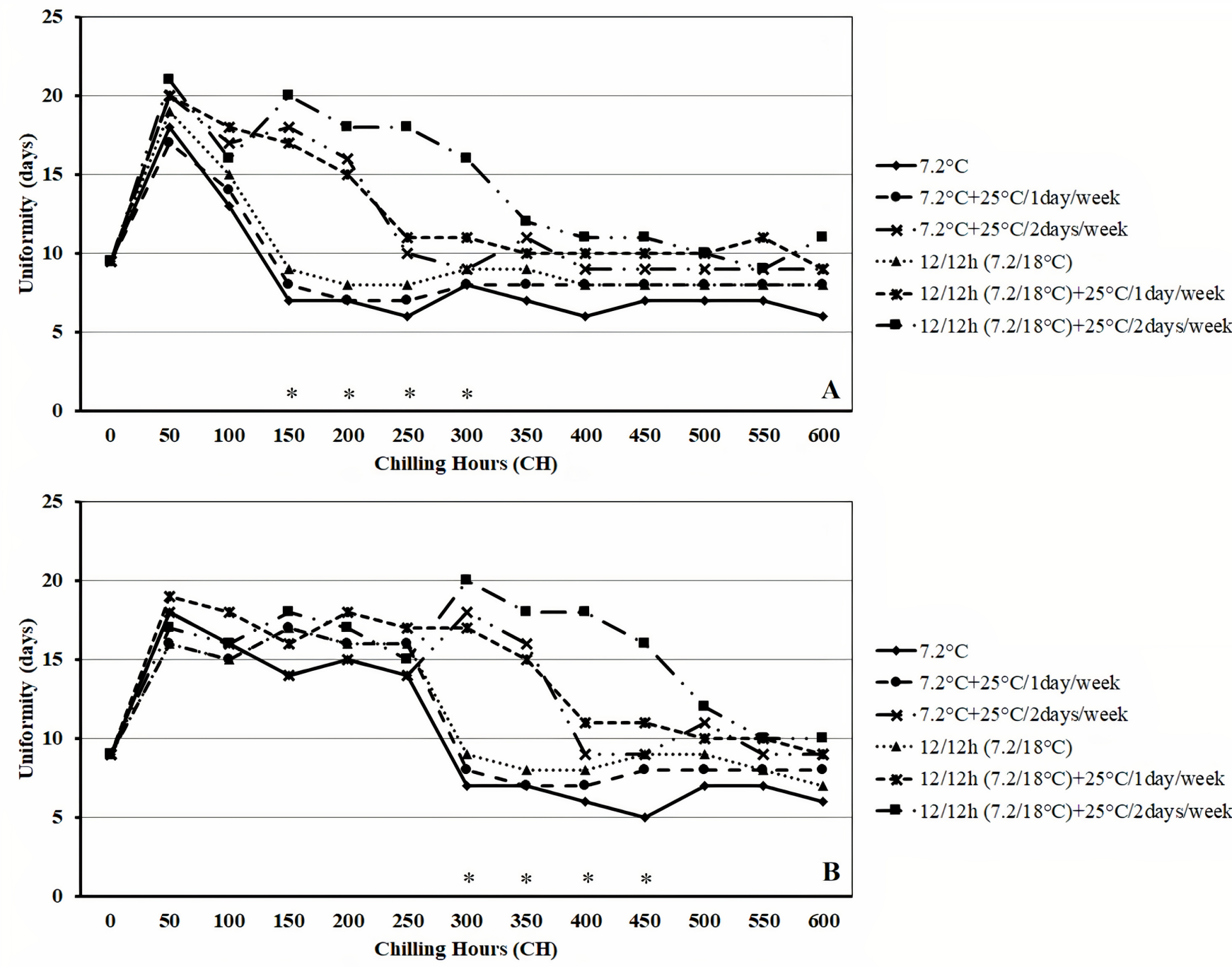

-๑ $7.2^{\circ} \mathrm{C}+25^{\circ} \mathrm{C} / 1$ day $/$ week

$\boldsymbol{*} \cdot 7.2^{\circ} \mathrm{C}+25^{\circ} \mathrm{C} / 2$ days $/$ week

..... 12/12h $\left(7.2 / 18^{\circ} \mathrm{C}\right)$

- $*-12 / 12 \mathrm{~h}\left(7.2 / 18^{\circ} \mathrm{C}\right)+25^{\circ} \mathrm{C} / 1$ day $/$ week

$\rightarrow \cdot 12 / 12 \mathrm{~h}\left(7.2 / 18^{\circ} \mathrm{C}\right)+25^{\circ} \mathrm{C} / 2$ days $/$ week

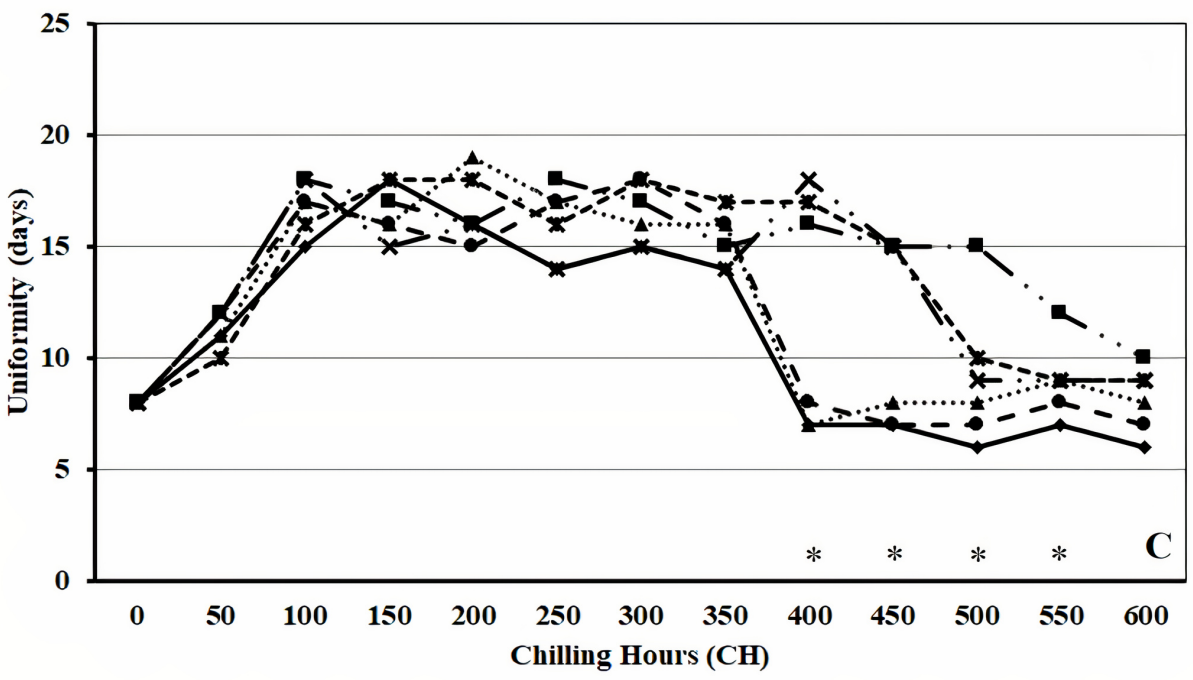

$\longrightarrow 7.2^{\circ} \mathrm{C}$

-๑ $7.2^{\circ} \mathrm{C}+25^{\circ} \mathrm{C} / 1 \mathrm{day} /$ week

$\boldsymbol{*} \cdot 7.2^{\circ} \mathrm{C}+25^{\circ} \mathrm{C} / 2 \mathrm{days} /$ week

$\cdots \wedge \cdot 12 / 12 \mathrm{~h}\left(7.2 / 18^{\circ} \mathrm{C}\right)$

- $*-12 / 12 \mathrm{~h}\left(7.2 / 18^{\circ} \mathrm{C}\right)+25^{\circ} \mathrm{C} / 1$ day/week

$\rightarrow \cdot 12 / 12 \mathrm{~h}\left(7.2 / 18^{\circ} \mathrm{C}\right)+25^{\circ} \mathrm{C} / 2$ days $/$ week

Figure 3 - Budburst uniformity of 'Chardonnay' (A), 'Merlot' (B) and 'Cabernet Sauvignon' (C) grapevines submitted to constant temperature of $7.2^{\circ} \mathrm{C}$, alternating temperatures of $7.2 / 18^{\circ} \mathrm{C}$ and heat waves in the middle of the cold during the dormancy period. Veranópolis, 2021. Significant differences in budburst uniformity, within each cold period, by the Tukey test $(\mathrm{p}<0.05)$, are marked with $\left({ }^{*}\right)$. Description of treatments: $7.2^{\circ} \mathrm{C} \rightarrow 7.2^{\circ} \mathrm{C}$ constant; $7.2^{\circ} \mathrm{C}+25^{\circ} \mathrm{C} / 1$ day $/$ week $\rightarrow 7.2^{\circ} \mathrm{C}$ constant with heat waves 1 day per week at $25^{\circ} \mathrm{C} ; 7.2^{\circ} \mathrm{C}+25^{\circ} \mathrm{C} / 2$ days/week $\rightarrow 7.2^{\circ} \mathrm{C}$ constant with heat waves 2 days per week at $25^{\circ} \mathrm{C} ; 12 / 12 \mathrm{~h}\left(7.2 / 18^{\circ} \mathrm{C}\right)+25^{\circ} \mathrm{C} / 1$ day/week $\rightarrow$ daily cycles of 12 hours at $7.2^{\circ} \mathrm{C}$ and 12 hours at $18^{\circ} \mathrm{C}$, with heat waves of 1 day per week at $25^{\circ} \mathrm{C} ; 12 / 12 \mathrm{~h}\left(7.2 / 18^{\circ} \mathrm{C}\right)+25^{\circ} \mathrm{C} / 2$ days/week $\rightarrow$ daily cycles of 12 hours at $7.2^{\circ} \mathrm{C}$ and 12 hours at $18^{\circ} \mathrm{C}$, with heat waves 2 days per week at $25^{\circ} \mathrm{C}$. 


\section{Conclusions}

Daily temperature cycles ranging from $7.2^{\circ} \mathrm{C}$ to $18^{\circ} \mathrm{C}$ do not affect the process of overcoming endodormancy.

Heat waves of $25^{\circ} \mathrm{C}$ during dormancy result in increase in the number of chilling hours to satisfy the chilling requirements of grapevine cultivars.

The negative effect of high temperatures depends on their duration, with heat partially canceling out the chill after 36 continuous hours on the dormancy.

Budburst precocity and uniformity are greater after supplying chilling during dormancy for each genotype.

\section{Acknowledgments}

The authors thank the National Council for Scientific and Technological Development (CNPq) for the financial support (project 424389/2018-5).

\section{References}

ALVAREZ, H.C.; SALAZAR-GUTIERREZ, M.; ZAPATA, D.; KELLER, M.; HOOGENBOOM, G. Timeto-event analysis to evaluate dormancy status of singlebud cuttings: an example for grapevines. Plant Methods, Melbourne, v.94, n.14, p.1-13, 2018.

ANZANELLO, R.; FOGACA, C. M. ; SARTORI, G. B. $D$. Induction and overcoming of dormancy of grapevine buds in response to thermal variations in the winter period. Ciência Rural, Santa Maria, v.51, n.11, e20200887, 2021.

ANZANELLO, R.; LAMPUGNANI, C.S. Requerimento de frio de cultivares de pessegueiro e recomendação de cultivo no Rio Grande do Sul. Pesquisa Agropecuária Gaúcha, Porto Alegre, v.26, n.1, p.18-28, 2020.

ANZANELLO, R. Evolution of the grapevine bud dormancy under different thermal regimes. Semina: Ciências Agrárias, Curitiba, v.40, n.6, p.3419-3428, 2019.
ANZANELLO, R.; FIALHO, F.B.; SANTOS, H.P. Chilling requirements and dormancy evolution in grapevine buds. Ciência e Agrotecnologia, Lavras, v.42, n.4, p.364-371, 2018.

ANZANELLO, R.; FIALHO, F.B.; SANTOS, H.P.; BERGAMASCHI, H.; MARODIN, G.A.B. Bud dormancy in apple trees after thermal fluctuations. Pesquisa Agropecuária Brasileira, Brasília, DF, v.49, n.6, p.457-464, 2014a.

ANZANELLO, R.; FIALHO, F.B.; SANTOS, H.P; BERGAMASCHI, H.; MARODIN, G.A.B. Métodos biológicos para avaliar a brotação de gemas em macieira para modelagem da dormência. Semina: Ciências Agrárias, Curitiba, v.35, n.3, p.1163-1176, 2014b.

BOTELHO, R.V.; PIRES, E.J.P.; MOURA, M.F.; TERRA, M.M.; TECCHIO, M.A. Garlic extract improves budbreak of the 'Niagara Rosada' grapevines on sub-tropical regions. Ciência Rural, Santa Maria, v.40, n.11, p.22822287,2010

CAMPOY, J.A.; RUIZ, D.; COOK, N.; ALLDERMAN, L.; EGEA, J. High temperatures and time to budbreak in low chill apricot 'Palsteyn'. Towards a better understanding of chill and heat requeriments fulfillment. Scientia Horticulturae, Amsterdan, v.129, n.4, p.649$655,2011$.

CARDOSO, L.S.; BERGAMASCHI, H. BOSCO, L.C.; PAULA, V.A.; MARODIN, G.A.B; CASAMALI, B.; NACHTIGALL, G.R. Disponibilidades climáticas para macieira na região de Vacaria, RS. Ciência Rural, Santa Maria, v.42, n.11, p.1960-1967, 2012.

CARVALHO, J.N.; PEREIRA, L.S.; CARVALHO, P.A.; DE CARLOS NETO, A. Application of natural garlic extract to overcome bud dormancy of grapevines 'BRS Rúbea' and 'BRS Cora'. Australian Journal of Crop Science, Queensland, v.10, n.2, p.216-219, 2016.

CARVALHO, R.I.N.; ZANETTE, F. Dinâmica do conteúdo de monossacarídeos em gemas e ramos de dois anos de macieira durante a endodormência. Ciência Rural, Santa Maria, v.36, n.4, p.1132-1137, 2006. 
CARVALHO, R. I. N.; BIASI, L. A.; ZANETTE, F.; SANTOS, J. M.; PEREIRA, G. P. Estádios de brotação de gemas de fruteiras de clima temperado para o teste biológico de avaliação de dormência. Revista Acadêmica de Ciências Agrárias e Ambientais, Curitiba, v. 8, n. 1, p. 93-100, 2010.

EBERT, A.; PETRI, J.L.; BENDER, R.J.; BRAGA, H.J. First experiences with chill-unit models in Southern Brazil: modelling in fruit research. Acta Horticulturae, The Hague, n.184, p.74-86, 1986.

EREZ, A.; LAVEE, S. The effect of climatic conditions on dormancy development of peach buds. Journal of the American Society for Horticultural Science, Alexandria, v.96, n.6, p.711-714, 1971.

EREZ, A. Bud dormancy: a suggestion for the control mechanism and its evolution. In: VIÉMONT, J.-D.; CRABBÉ, J. (ed.). Dormancy in plants: from whole plant behaviour to cellular control. Wallingford: $C A B$ International, 2000. p.23-33.

FELIPPETO, J.; BERGONCI, J.I.; SANTOS, H.P.; NAVA, G. Modelos de previsão de brotação para a cultivar de videira Cabernet Sauvignon Na Serra Gaúcha. Agropecuária Catarinense, Florianópolis, v.26, n.1, p. 85-91, 2013.

GUO, L.; DAI, J.; RANJITKAR, S.; YU, H.; XU, J.; LUEDELING, E. Chilling and heat requirements for flowering in temperate fruit trees. International Journal of Biometeorology, Lisse, v.58, n.6, p.1195-1206, 2014.

HAWERROTH, F.J. PETRI, J.L.; LEITE, G.B.; HERTER, F.G.; MARAFON, A.C. Efeito do frio e do desponte na brotaçãode gemas em pessegueiro. Revista Brasileira de Fruticultura, Jaboticabal, v.31, n.2, p.440-446, 2009.

HAWERROTH, F.J.; HERTER, G.F.; PETRI, J.L.; LEITE, G.B.; PEREIRA. J.F.M. Dormência em frutíferas de clima temperado. Pelotas: EMBRAPA Clima Temperado, 2010. 56 p. (Documentos, 310)

LANG, G.A. EARLY, J.D.; MARTIN, G.C.; DARNELL, R.L. Endo-, para- and ecodormancy: physiological terminology and classification for dormancy research. Hortscience, Alexandria, v.22, n.3, p.371-178, 1987.
LEGAVE, J.M.; FARRERA, I.; ALMERAS, T.; SANTAMARIA, P.; CALLEJA, M. Selecting models of apple flowering time and understanding how global warming has had an impact on this trait. Journal of Horticultural Science and Biotechnology, London, v.83, n.1, p.76-84, 2008.

LEITE, G. B.; BONHOMME, M.; PUTTI, G. L.; PETEL, G.; PETRI, J. L.; RAGEAU, R. Physiological and biochemical evolution of peach leaf buds during dormancy course under two contrasted temperature patterns. International Journal of Horticultural Science, Budapest, v.12, n.4, p. 15-19, 2006.

LUEDELING, E.; BROWN, P.H. A global analysis of the comparability of winter chill models for fruit and nut trees. International Journal of Biometeorology, Lisse, v. 55, n. 3, p.411-421, 2011.

MARAFON, A.C.; CITADIN, I.; AMARANTE, L.; HERTER, F.G.; HAWERROTH, F.J. Chilling privation during dormancy period and carbohydrate mobilization in Japanese pear trees. Scientia Agricola, Piracicaba, v. 68, n. 4, p. 462-468, 2011.

NAOR, A.; FLAISHMAN, M.; STERN, R.; MOSHE, A.; EREZ, A. Temperature effects on dormancy completion of vegetative buds in apple. Journal of the American Society for Horticultural Science, Mount Vernon, v. 128, p. 636-641, 2003.

NIGHTINGALE, G. T; BLAKE, M. A. Effects of temperature on the growth and composition of Stayman and Baldwin apple trees. New Jersey: New Jersey Agricultural Experiment Station, 1934. (Bulletin, 566).

PETRI, J.L.; SEZERINO, A.A.; HAWERROTH, F.J.; PALLADINI, L. A.; LEITE, G.B.; DE MARTIN, M.S. Dormência e indução à brotação de árvores frutíferas de clima temperado. Florianópolis: Epagri, 2021, 153p. (Boletim Técnico, 192).

RICHARDSON, E. A; SEELEY, S. D; WALKER, D. R. A model for estimating the completion of rest for 'Redhaven' and 'Elberta' peach trees. HortScience, Alexandria, v.9, n.4, p.331-332, 1974. 
SHALTOUT, A.D; UNRATH, C.R. Rest completion prediction model for 'Starkrimson Delicious' apples. Journal of the American Society for Horticultural Science, Alexandria, v.108, n.6, p.957 961, 1983.

WAGNER JUNIOR, A.; BRUCKNER, C.H.; PIMENTEL, L.D.; RASEIRA, M.C.B. Evaluation of chilling requirement in peach through grafted twigs. Acta Horticulturae, The Hague, n.713, p.243-246, 2006.
WATANABE, C.Y.; COSER, G.M.A.G.; SILVA, M.J.R.da; TECCHIO, M.A.; HAWERROTH, F.J.; ALBOLÉA, M.N. Uso de Erger ${ }^{\circledR}$ associado ao nitrato de cálcio na produção e qualidade de uvas "Niagara Rosada" cultivadas em Botucatu, SP. In: ENCONTRO NACIONAL DE FRUTICULTURA DE CLIMA TEMPERADO, 15 ., 2017, Fraiburgo. Anais [...] Florianópolis: Epagri, 2017. Disponível em: https://ainfo.cnptia.embrapa.br/ digital/bitstream/item/168986/1/Watanabe-Resumo-XVEnfrute-2017.pdf. Acesso em: 27 set. 2021.

WEINBERGER, J.H. Chilling requirements of peach varieties. Proceedings of the American Society for Horticultural Science, Mount Vernon, v.56, n.1, p.122$128,1950$. 